\title{
İnternetdə uşaqların fordi məlumatlarının qorunması vəziyyətinin analizi
}

\author{
Sabirə Ocaqverdiyeva \\ AMEA İnformasiya Texnologiyaları İnstitutu, Bakı, Azərbaycan \\ allahverdiyevasabiraas@gmail.com
}

\begin{abstract}
Xülasə - Məqalədə uşaqların fərdi məlumatlarının qorunması aktual təhlükəsizlik problemi kimi qeyd edilir. Uşaq və yeniyetmələrin fordi məlumatlarının qorunması məqsədilə beynəlxalq aləmdə qəbul edilmiş rəsmi sənədlər şərh edilir. Uşaqların fərdi məlumatlarının əldə edilməsində rəqəmsal qurğuların rolu göstərilir. Ölkəmizdə uşaqların fərdi məlumatlarının mühafizəsi ilə əlaqədar bir sıra təkliflər irəli sürülür.
\end{abstract}

Açar sözlor: fordi molumatlar, molumatların moxfiliyi, uşaqların fordi molumatları, roqəmsal oşyalar

\section{GİRIŞ}

İnternetin inkişafı informasiya texnologiyaları ilə qarşılıqlı münasibətlərin yeni formalarının yaranmasına səbəb olur. Süni intellekt, Big data texnologiyaları ilə təchiz olunmuş qurğulardan istifadənin ənənəvi hal alması informasiya mübadiləsini sürətləndirməklə yanaş1, həyatın bütün sahələrində qərarların qəbulu üçün vacib faktora çevrilir [1].

Real həyatda olan məlumatların əksəriyyəti virtual mühitə transformasiya olunur. Bu sürətli informasiya mübadiləsi prosesinin təsiri ilə real və virtual aləmlər arasında fərqlər azalır. Cəmiyyət texnologiyaya əsaslanan aktivlərini fərdi, korporativ və milli təhlükəsizlik səviyyəsində olan təhdidlərdən qorunmalı olduğunu qəbul edir. $\mathrm{Bu}$ isə cəmiyyətdə fərdi və ictimai məlumatlar arasında tarazlığın təhlil olunmasına ehtiyac yaradır [2].

İnternet istifadəçilərinin müəyyən hissəsi uşaq və yeniyetmələrdir [3]. Onlar virtual mühitdə aktivdirlər, interaktiv media mədəniyyətinin təsiri ilə fəaliyyət göstərir və qlobal bir cəmiyyətin üzvünə çevrilirlər. Onlar üçün sosial şəbəkələrdə öz profillərini və statuslarını tez-tez yeniləmək, gündəlik həyat fəaliyyətləri və olduqları məkan haqqında məlumatları paylaşmaq, dostları ilə məktublaşmaq, onlayn fikir mübadiləsi aparmaq adi davranışa çevrilmişdir [3]. İstifadəçilərin maraqlarını, davranışlarını və vərdişlərini ələ keçirmək istəyən təşkilatlar, şirkətlər və şəxslər üçün İnternet zəngin informasiya mənbəyi kimi məlumat çatdırma mexanizmi olaraq xidmət edir.

Yeni iştirakçı platformalar gənclərin sosiallaşması üçün əlverişli şərait yaradır, eyni zamanda onların fərdi məlumatlarının qorunması məsələsini aktuallaşdırır [4].
İnternet istifadəçilərinin əksəriyyəti məlumatların gizli saxlanması, xüsusi ilə də fərdi məlumatlatların gizliliyi haqqında müəyyən biliklərə malikdir. Gizlilik tədbirləri kimi parollardan, mürəkkəb açarlardan, identifikatorlardan, elektron imzalara qədər xüsusi hazırlanmış müxtəlif vasitələrdən istifadə edilir. $\mathrm{Bu}$ gizlilik tədbirlərinin mövcud olmasına baxmayaraq istifadəçilərin fərdi məlumatlarının yayılması və düzgün istifadə edilməməsi riski olduqca yüksəkdir. Beləki, İnternetdən istifadə zamanı istifadəçilərin qarşılaşdığı təhlükələrin siyahısında fərdi məlumatların qorunması və idarə olunması xüsusi yer tutur.

Uşaqların fərdi məlumatları onların özləri, valideyinləri və marketinq şirkətləri tərəfindən şəbəkədə yerləşdirilməsi paylaşıla bilər. Rəqəmsal qurğuların sayının gündən-günə artması, təkmilləşdirilməsi uşaqların fəaliyyətini dəyişdirir, onların gündəlik həyatı haqqında məlumatları müxtəlif informasiya sistemlərinə ötürülür. $\mathrm{Bu}$ məlumat bazalarından valideynlər, tədris, səhiyyə, sığorta, bank və bir sıra təşkilatlar maksimum faydalanmağa çalışır. Lakin bu məlumatlar uşaqlara qarşı yönəlmiş bir təhdid mənbəyi ola bilər. Bədniyyətli insanlar tərəfindən müəyyən məqsədlər üçün istifadə oluna bilər.

\section{RӘQӘMSAL QURĞULAR UŞAQLARIN FӘRDI MOLUMATLARININ DAŞIYICISI KIMI}

Son zamanlar müxtəlif rəqəmsal qurğular uşaqların həyatına inteqrasiya edilmişdir. $\mathrm{Bu}$ inteqrasiya prosesi dərinləşməkdə davam edir, çünki Big data prinsipləri və təcrübələri rəqəmsal mənzərəni dəyişdirməyə nail olmuşdur. Nəticədə fərdi məlumatların toplanması, izlənməsi və marketinqini həyata keçirən tətbiqetmələr meydana gəlmişdir. Bütün bunlar isə uşaqların fərdi məlumatları üzərində biznes maraqları olan bədniyyətli insanların fəaliyyətinə kömək edir.

Uşaqların həyatında sensorla təchiz olunmuş oyuncaqlar, nəzarətçi cihazlar, müxtəlif tapşırıqları xatırladan və uşaqların fəaliyyətini izləyən qurğular və s. əhəmiyyət kəsb edir. Rəqəmsal oyuncaqlar konkret zaman çərçivəsində uşaqların davranışları haqqında olan məlumatları işıq və ya xüsusi siqnallar vasitəsilə məlumat bazasına toplayır [5].

Müəyyən müddətdən sonra uşağın marağı mobil qurğulara, kompüterə, planşetlərə və digər müasir texnologiyalara 


\section{“Informasiya tohlükosizliyinin aktual multidissiplinar elmi-praktiki problemlori” \\ V respublika konfransl, 29 noyabr 2019-cu il}

yönəlir. Artıq uşaqların rəqəmsal texnologiyalardan istifadəsi adi maus və klaviatura ilə deyil, interfeys və qurğular sensor ekran və jestlərin tanınma qurğuları kimi müasir qarşılıqlı münasibət formaları ilə əvəz edilir.

Oşyaların İnterneti məhz rəqəmsal texnologiyaların təzahürüdür. və uşaqların əşyalarla münasibəti haqqında məlumat əldə etməyə qadirdirlər [6]. Oşyaların İnterneti şəbəkəyə qoşulmuş kompüterlərin eyni zamanda əşyalarla bağlılığını göstərir. Oşyaların İnterneti vasitəsilə fərdi məlumatların toplanması ənənəsi genişləndikcə fərdi məlumatların təhlükəsizliyi problemi də böyüməkdə davam edir. $\mathrm{Bu}$ intellektual avadanlıqlar və qurğular yalnız məlumat toplayan xüsusi sensorlarla təchiz olunmur, onlar qlobal şəbəkə vasitəsilə həmin məlumatları emal edən qurğulara qoşulur.

Valideynlər övladlarının onlayn fəaliyyətlərinin onun məxfiliyinə necə təsir göstərməsi ilə bağlı narahatlıq keçirir. Belə tədbirlərin həyata keçirilməsində təhsil müəssisələri də maraqlı olurlar. Məktəb rəhbərləri öz şagirdlərinin təhlükəsizliyini təmin etmək üçün yeni yollar axtarır. Buna misal olaraq Yaponiya və ABŞ-dakı bəzi məktəb rəhbərlərinin şagirdlərin döş nişanlarına, geyimlərinə və ya məktəb çantalarına identifikasiya etiketlərinin yerləşdirilməsini göstərmək olar [7].

Rəqəmsal əşyalar vasitəsilə uşaqların izlənməsi onların harada olduğu, hansı fəaliyyətlə məşğul olduğu, yuxu rejimini və s. izlənməkdə faydalıdır. Çünki valideyn övladı haqında anında məlumat əldə edir, lakin bu izlənmənin mənfi cəhətləri kimi aşağıdakıları qeyd etmək olar:

- Uşaqların fərdi məlumatları müxtəlif məlumat bazalarına ötürülür;

- Uşaqlardan əşya kimi, sanki bir obyekt kimi istifadə olunur;

- Valideyn müəyyən qərar qəbul edərkən, məlumat bazalarına əsaslanır ki, bu zaman uşağın fikri ikinci plana keçir.

Rəqəmsal əşyaların həyatımıza nüfuz etməsi faydalıdır. Lakin, evlərdə və məktəblərdə rəqəmsal texnologiyaların geniş tətbiqi yeni sosial problemlərin ortaya çıxmasına səbəb olur.

\section{UŞAQLARIN FORDİ MOLUMATLARI İLO BAĞLI HÜQUQİ TONZIMLOMӘLӘR}

Uşaqlar olayn təhlükələr və onların yaratdığı mənfi nəticələr haqqında az məlumatlı olduqları üçün onların böyüklərdən bir qədər də artıq müdafiəyə ehtiyacı vardır. Beynəlxalq aləmdə uşaqların fərdi məlumatlarının istifadəsi ilə əlaqəli rəsmi sənədlər bu məsələləri əhatə edir.

1998-ci ildə Uşaqların İnternetdə Gizliliyinin Qorunması Qanunu (ing. The Children's Online Privacy Protection Act COPPA) qəbul edilmişdir. Bu qanun veb sayt operatorunun məxfilik siyasətinə nə daxil etməli olduğunu, valideyndən və ya qəyyumdan təsdiqlənən razılığı nə vaxt və necə istəməli olduğunu, operatorun onlayn rejimdə uşaqların məxfiliyini və təhlükəsizliyini qorumaq üçün hansı məsuliyyəti özündə cəmləşdirməsini, o cümlədən marketinqdə hansı məhdudiyyətlərin daxil edilməsini özündə əks etdirir. Qanun Birləşmiş Ştatların qanunvericiliyinə əsasən 13 yaşına çatmamış şəxslərin və ya təşkilatlarda olan şəxsi məlumatların toplanmasina aiddir [8].

Qanun kommersiya veb-saytlarının və digər medyanın 13 yaşdan kiçik uşaqların şəxsi məlumatlarının toplanmasını məhdudlaşdırmağı tələb edir. Valideynlərin cəlb olunması üçün mexanizm təklif edir və verilənlərin adekvat aşkarlanması və mühafizəsi üçün məsuliyyəti şirkətlərin öhdəliyinə verir.

$\mathrm{Bu}$ qanunun icrası ilə bağlı qaydalar bəzi yeni yaranan problemlərə və təcrübələrə cavab vermək üçün 2013-cü ildə yenilənmişdir. Qanuna davranış hədəflərinə, fərdiləşdirilmiş reklam və məkana əsaslanan məhdudiyyətlər əlavə edilmişdir.

COPPA uşaqları onlar haqqında olan, tövsiyə olunmayan məlumatların toplanmasından və hədəfli marketinq taktikalarından mühafizə edir. Bu hədəflərə baxmayaraq, qanun böyük məhdudiyyətlərə malikdir. Beləki, COPPA yalnız 13 yaşdan kiçik uşaqlara tətbiq edildiyi üçün yeniyetmələrin informasiya təhlükəsizliyini (kommersiya, rəqəmsal media mühitində fərdi məlumatların gizliliyi) təmin etmir [8].

İnternetdə uşaqların məlumatlarını qorumaq, uşaqların onlayn məxfiliyinin pozulması məsələləri Avropa qanunvericiliyində ön plandadır.

Məlumatların Qorumasının Ümumi Qaydası (ing. General Data Protection Regulation - GDPR) Avropa Birliyi (AB) tərəfindən 25 may 2018-ci ildə qüvvəyə minmişdir. Bu qanun həm uşaqlar, həm də böyüklər üçün nəzərdə tutulur. Qanun uşaqların məlumatlarını qorumağı hədəfləyən müəyyən müddəaları əhatə edir [9].

Bu qayadalara əsasən uşaqların yaş həddi olaraq - 16 yaş götürülür. Bəzi üzv dövlətlərdə isə bir qədər aşağı yaş həddi olaraq 13 yaş kimi qəbul edilir. Uşaqların və məlumatlarının qorunmasına dair GDPR prinsiplərinə aşağıdakılar daxildir [10]:

- Fərdi məlumatlar toplandiqda və emal olunduqda uşaqlar üçün xüsusi tətbiqlər olunmalıdır, çünki onlar potensial risklərdən az xəbərdardırlar;

- Ogər bir təşkilat uşaqların məlumatlarını emal edirsə və ya onların gələcəkdə hər hansı bir məqamda olacağını düşünürsə, əvvəlcədən müəyyən üsul və vasitələrdən istifadə etməlidir;

- Uşaqların bütün məlumatlarının işlənməsi zamanı məlumatların qorunması prinsiplərinə uyğunluq nəzərə alınmalıdır; 


\section{“Informasiya tohlükssizliyinin aktual multidissiplinar elmi-praktiki problemlori” \\ V respublika konfransl, 29 noyabr 2019-cu il}

- Hər hansı bir uşağın şəxsi məlumatlarının işlənməsi üçün qanuni əsası olmalıdır. Razılıq mümkün bir qanuni əsasdır, ancaq bu yeganə seçim deyil və alternativ bir əsas daha uyğun ola bilər ki, bu da uşağın daha yaxşı qorunmasını təmin edər;

- Uşaqlara onlayn xidmət təqdim edərkən fərdi məlumatların emalı üçün qanuni əsas kimi yalnız 13 yaşdan yuxarı uşaqlar öz razılığını təmin edə bilərlər. Buna görə, məsləhət və ya profilaktik xidmət olmadıqda 13 yaşdan kiçik uşaqlar üçün valideyn və ya məsuliyyət daşıyan şəxsdən razılıq alınmalıdır;

- Uşaqlar haqqında avtomatik olaraq qərar qəbul edilməməlidir. Təşkilatlar uşaqlara onların fərdi məlumatlarından necə istifadə edəcəklərini açıq şəkildə bildirməlidirlər. İştirak edən risklər və təhlükəsizlik tədbirləri barədə açıq olduqlarını təmin etməlidirlər. Təşkilatlar məlumatların necə istifadə olunduğuna görə xoşa gəlməz hal olduğu təqdirdə uşaqlara nə edəcəyini düşünməlidir;

- Uşaqlara yönəlmiş riskləri qiymətləndirmək, onların sayını və təsirini azaltmaq üçün Məlumatların Mühafizəsinə Təsirin Qiymətləndirmələrindən (Data Protection Impact Assessments -DPIA) istifadə edilmolidir;

- Təşkilatlar uşaqlarla münasibət qurarkən, onlara onlayn xidmətlər təqdim edərkən aydın və asan başa düşülən bir dildən istifadə etməlidirlər;

- Fordi məlumatların silinməsi hüququ, şəxsin uşaq yaşında ikən işlənməyə razılıq verdikdə aktualdır.

Cədvəl 1. -də uşaqların məlumatları emal edilərkən onların yaş baxımından fərdi məlumatlarının işlənməsinə dair məlumat verilir. $\mathrm{Bu}$ cədvəldə $\mathrm{AB}-\mathrm{y}$ ○ daxil olan ölkələrin adları, qanun qəbul edildiyi il və uşağın yaş həddi göstərilir.

CODVӘL 1. Fərdi məlumatlarının işlənməsinə dair AB ölkələri üzrə paylanma

\begin{tabular}{|c|c|c|c|}
\hline SS & Ölkə & $\begin{array}{c}\text { Qanun qəbul } \\
\text { olunduğu il }\end{array}$ & $\begin{array}{c}\text { Uşağın } \\
\text { yaş } \\
\text { həddi }\end{array}$ \\
\hline 1 & Belçika & 2018 & 13 \\
\hline 2 & Danimarka & 2018 & 13 \\
\hline 3 & Estoniya & 2019 & 13 \\
\hline 4 & Finlandiya & 2018 & 13 \\
\hline 5 & Malta & 2018 & 13 \\
\hline 6 & Latviya & 2018 & 13 \\
\hline 7 & İsveç & 2018 & 13 \\
\hline 8 & Portuqaliya & 2019 & 13 \\
\hline 9 & Birləşmiş Krallıq & 2018 & 13 \\
\hline 10 & Avstriya & 2018 & 14 \\
\hline 11 & Bolqarıstan & 2019 & 14 \\
\hline 12 & Kipr & 2018 & 14 \\
\hline 13 & İtaliya & 2018 & 14 \\
\hline 14 & Litva & 2018 & 14 \\
\hline 15 & İspaniya & 2018 & 14 \\
\hline
\end{tabular}

\begin{tabular}{|c|c|c|c|}
\hline 16 & Çexiya & 2019 & 15 \\
\hline 17 & Fransa & 2018 & 15 \\
\hline 18 & Xorvatiya & 2018 & 16 \\
\hline 19 & Almaniya & 2018 & 16 \\
\hline 20 & Macarıstan & 2018 & 16 \\
\hline 21 & İrlandiya & 2018 & 16 \\
\hline 22 & İngiltərə & 2018 & 16 \\
\hline 23 & Lüksemburq & 2018 & 16 \\
\hline 24 & Hollandiya & 2018 & 16 \\
\hline 25 & Slovakiya & 2018 & 16 \\
\hline 26 & Rumıniya & 2018 & 16 \\
\hline
\end{tabular}

AB-yə üzv olmayan, lakin Avropa İqtisadi Bölgəsinin üzvü olan dövlət kimi Norveç 2018-ci ilin may ayında GDPR-ni tətbiq edən yeni Fərdi Məlumat Aktını təsdiqləmişdir. Qanunda uşaqların rəqəmsal xidmətlərə razılıq yaşının 13 olduğunu bildirmişdir [10].

Hal hazırda Yunanıstan və Sloveniya kimi ölkələr isə öz milli tətbiqetmə qanunlarını gözləyirlər. $\mathrm{Bu}$ ölkələrdə qanun layihəsi rəsmi qəbul olunanadək təklif olunan yaş əvəzinə GDPR tərəfindən tətbiq edilən 16 yaş həddi öz quvvəsində qalir.

\section{TəKLIF VӘ TÖVSIYЭLӘR}

Araşdırmalardan məlum olur ki, dünyanın bir çox ölkələrində uşaların fərdi məlumatlarının qorunması müxtəlif hüquq müstəvilərdə öz həllini tapır. Yeni qanunlar, aktlar qəbul edilir və ya əvvəlcədən qəbul edilmiş qanuna uşaqların fərdi məlumatlarının qorunması ilə bağlı əlavələr edilir. Bu qanunlarda bir əsas məqsəd də uşaqların açıq məlumatlarının istifadəsi və gələcəkdə onlara qarşı yönəlmiş potensial risklərin qarşısının alınmasıdır.

Ölkəmizdə uşaqların fərdi məlumatlarının qorunması vacib məsələlərdəndir. Bu problemin həllinın yaxşılaşdırılması ilə əlaqədar olaraq aşağıda qeyd edilən tədbirlərin icrası işə öz müsbət təsirini göstərə bilər:

1. Azərbaycanda uşaqların fordi məlumatlarının mühafizəsi ilə bağlı qanunun qəbul edilməsi;

2. Rəqəmsal kompetensiyanın artırılması üçün metodik vəsait və dərsliklərin hazırlanması;

3. Rəqəmsal cəmiyyətin faydalarını optimallaşdırmaq üçün uşaq və gənclər üçün adekvat hazırlığın təşkil edilməsi;

4. Uşaq və yeniyetmələrə İnternet təhlükələri, fərdi məlumatların İnternetdə paylaşılması və qorunması ilə bağlı təlimlərin təşkil edilməsi;

5. Kiçik yaşlarından uşaqlara məlumat mübadiləsi riskləri barədə məlumatlandırmaq üçün əlavə işlərin görülməsi;

6. Uşaqların fordi məlumatların toplanmasında Oşyaların İnterneti çox böyük əhəmiyyətə malik oluğundan, fərdi məlumatların ələ keçirilməsi risklərini azaltmaq məqsədilə Oşyaların İnternetinin tətbiqində normativ- 


\section{“Informasiya tohlükosizliyinin aktual multidissiplinar elmi-praktiki problemlori” V respublika konfransı, 29 noyabr 2019-cu il}

hüquqi tənzimləmə, kibertəhlükəsizlik və standartlaşdırma məsələlərin həlli edilməsi.

Məlumdur ki, rəqəmsal bir dünyanın vətəndaşı olmaq məsuliyyətlidir, uşaq və yeniyetmələr üçün bir qədər çətindir. Texnologiyalar qlobal əlaqələri asanlaşdırmaqla yanaşı, istifadəçiləri təhlükələrlə üz-üzə qoyur. Buna görə də texnologiyalardan təhlükəsiz istifadə zamanı yaranmış problemləri uğurla həll etmək üçün uşaqlara davamlı rəhbərlik etmək lazımdır. Hər bir uşaq və yeniyetmənin rəqəmsal yetkinliyi inkişaf etdirilməlidir. $\mathrm{Bu}$ vəzifə yetkinlərin, mütəxəssislərin və təhsil müəssisələrinin əsas hədəflərindən birinə çevrilməlidir.

\section{NəTİCə}

Müasir uşaq və yeniyetmələr rəqəmsal medya mədəniyyətinin təsiri ilə böyüyürlər. İstifadəçilərin əksəriyyəti müasir informasiya texnologiyalarının iş prinsipidən, övladlarının davranışlarının ağıllı qurğular vasitəsilə necə qeydə alındığından və bu məlumatlardan hansı məqsədlərlə istifadə edildiyindən xəbərdar deyildir. Rəqəmsal qurğuların uşaqların davranışına nə dərəcədə təsir etməsi, həmin qurğular vasitəsilə əldə olunan fərdi məlumatların necə istifadə olunmas1, bu barədə valideyinlərin xəbərdar olub-olmamas1 məsələləri aktual olaraq qalmaqda və mütəxəssisləri düşündürməkdədir.

Fərdi məlumatlarını İnternetdə rəqəmsallaşdırmağa meylli olan şəxslər daha çox yeniyetmələr və gənclərdir. Onlar onlayn məxfiliklə bağlı məlumatlı olsalar da, çox vaxt bu qaydaları unudurlar. Nəticədə özlərini bədniyyətli insanların hədəfinə çevrilirlər.

Məxfilik təhdidləri və uşaqların məxfiliyini necə qorumaq bu gün cəmiyyətdə həlli vacib olan problemlərdəndir. Bu sahədə biliklərin olması faydalıdır. Uşaqların fərdi məlumatları, tibbi məlumatları, psixoloji məlumatları, təhsil səviyyəsi, davranışları və s. bağlı statik məlumatlar onların gələcək həyatında problemlərin yaranmasına səbəb ola bilər.

\section{İSTINADLAR}

[1] R.Alguliyev and Y.Imamverdiyev, "Big Data: Big Promises for Information Security", Proceedings of the 8th International Conference on Application of Information and Communication Technologies (AICT), 15-17 Oct. 2014, IEEE, Astana, pp. 1-4.

[2] Г. Солдатова, О Теславская, «Персональные данные и дети: вопросы безопасности?», Эпоха науки, 2017 г, № 12, стр.92-102.

[3] R. Alguliyev and S. Ojagverdiyeva, "Conceptual Model of National Intellectucal System for Children Safety in Internet Environment", International Journal of Computer Network and Information Security(IJCNIS), 2019, №3. pp. 40-47.

[4] Unicef - The state of the world's children, 2017, 251p., https://www.unicef.org/publications/files/sowc_2017_eng_web.pdf

[5] G Maria., E Gabriela and J. Hernando, "Kids and Parents Privacy Exposure in the Internet of Things: How to Protect Personal Information?", Computación y Sistemas, 2018, vol. 22, No. 4, pp. 11911205.

[6] R.Oliquliyev, R. Mahmudov, “Oşyaların İnterneti: mahiyyəti, imkanları və problemləri”, İnformasiya cəmiyyəti problemləri, 2011, №2. s. 29-40.

[7] I.Berson and M.Berson, "Children and Their Digital Dossiers: Lessons in Privacy Rights in the Digital Age", International Journal of Social Education, 2006, vol. 21, n1 pp. 135-147.

[8] Children's Online Privacy Protection Rule (COPPA) // Federal Trade Commission official website, USA. URL: https://www.ftc.gov/enforcement/rules/rulemakingregulatory-reformproceedings/childrens-online-privacy-protection-rule.

[9] General Data Protection Regulation, https://gdpr-info.eu/

[10] The GDPR child's age of consent for data processing across the EU one year later, 2019 July, https://www.betterinternetforkids.eu

\section{ANALYSIS OF THE PROTECTION CHILDREN'S PERSONAL DATA ON THE INTERNET}

Sabira Ojagverdiyeva

Institute of Information Technology of ANAS, Baku, Azerbaijan

$$
\text { allahverdiyevasabira@gmail.com }
$$

Abstract - The protection of children's personal data is noted as a actual security issue in the article. The official documents recognized internationally are interpreted to protect the personal information of children and adolescents. The role of digital devices in acquiring children's personal data is shown. A number of suggestions are being put forward to protect the personal information of children in our country.

Keywords - personal information, data confidentiality, children's personal information, digital things 